\title{
The effect of the Brassica oleracea extract on the structural components of mucous cells of the stomach in its ulcerative damage
}

Aim. To study the effect of the Brassica oleracea extract on the total content of proteins and lipids of mucous cells of the stomach in the experimental ulcer.

Materials and methods. On the model of alcohol-prednisolone ulcer in rats the effect of the Brassica oleracea extract on the content of proteins and lipids of the mucous cells of the stomach was studied. To study the phospholipid content of membranes the lipid fraction was separated by Folch method. Separation of phospholipids into separate fractions was carried out by thin layer chromatography on silica gel. The protein spectrum of the stroma was studied by gel chromatography.

Results and discussion. The mechanism of the reparative action of the Brassica oleracea extract in the experimental gastric ulcer consisted in formation of a new fraction of proteins with the molecular mass of $36 \mathrm{kDa}$ and restoration of the lipid content of the gastric mucosa. It was accompanied with normalization of the structural and functional state of the mucosa by the restitution type with complete restoration of the mucous membrane.

Conclusions. The Brassica oleracea extract in ulcerative damage of the stomach promotes the processes of regeneration of proteins and lipids on the mucous cells of the stomach leading to reparation.

Key words: extract; Brassica oleracea; gastric ulcer; proteins; lipids; reparation

Н. М. Кононенко, М. Т. Мірзалієв, М. О. Остапець

Вплив екстракту капусти городньої на структурні компоненти клітин слизової оболонки шлунка при її виразковому ураженні

Мета - дослідження впливу екстракту капусти городньої на загальний склад білків та ліпідів клітин слизової оболонки шлунка при експериментальній виразці.

Матеріали та методи. На моделі спирто-преднізолонової виразки у щурів досліджено вплив екстракту капусти городньої на білковий і ліпідний склад клітин слизової оболонки шлунка. Для вивчення фоссооліпідного складу мембран відокремлювали ліпідну фрракцію за методом Фолча. Розділення фоссфоліпідів на окремі фракції проводили методом тонкошарової хроматограффії на силікагелі. Білковий спектр строми досліджували за допомогою гель-хроматографії.

Результати та їх обговорення. Механізм репаративної дії екстракту капусти городньої при експериментальній виразці шлунка полягає в утворенні нової фракції білків з молекулярною масою 36 кДа та відновленням ліпідного складу клітин СОШ, що супроводжувалося нормалізацією структурно-функціонального стану слизової оболонки за типом реституції - з повним ії відновленням.

Висновки. Екстракт капусти городньої при виразковому ураженні шлунка сприяє процесам регенерації білків та ліпідів у клітинах слизової оболонки шлунка, що приводить до ії репарації.

Ключові слова: екстракт; капуста городня; виразка шлунка; білки; ліпіди; репарація

Н. Н. Кононенко, М. Т. Мирзалиев, М. А. Остапец

Влияние экстракта капусты огородней на структурные компоненты клеток слизистой оболочки желудка при ее язвенном поражении

Цель - исследование влияния экстракта капусты огородной на общий состав белков и липидов клеток слизистой оболочки желудка при экспериментальной язве.

Материалы и методы. На модели спирто-преднизолоновой язвы у крыс исследовано влияние экстракта капусты огородной на белковый и липидный состав клеток слизистой оболочки желудка. Для изучения фоссфолипидного состава мембран отделяли липидную фракцию по методу Фолча. Разделение фоссфолипидов на отдельные фрракции проводили методом тонкослойной хроматографии на силикагеле. Белковый спектр стромы исследовали с помощью гель-хроматографии.

Результаты и их обсуждение. Механизм репаративного действия экстракта капусты огородной при экспериментальной язве желудка заключается в образовании новой фрракции белков с молекулярной массой 36 кДа и восстановлении липидного состава клеток СОЖ. Это сопровождалось нормализацией структурно-фуннционального состояния слизистой оболочки по типу реституции - с полным восстановлением слизистой оболочки.

Выводы. Экстракт капусты огородной при язвенном поражении желудка способствует процессам регенерации белков и липидов в клетках слизистой оболочки желудка, что приводит к ее репарации.

Ключевые слова: экстракт; капуста огородная; язва желудка; белки; липиды; репарация 
Gastric and duodenal ulcers are the most common diseases of the internal organs, according to the data of the world statistics they are distributed in about $10 \%$ of the adult population.

The leading role in initiating ulcer belongs to disorders of physicochemical and biochemical processes at the level of the epithelial mucous cells of the stomach (MCS). Proteins and lipids are the main structural components of cells in the cellular metabolism; they play a key role in reception, general regulation of intracellular processes. The basis of the cell structure disorders is a complex of interconnected and interdependent processes covering both the protein and lipid phases. It is clear that the change in the viscosity of cellular lipids determines the structural lability of proteins [1]. Therefore, the studies of the protein and lipid content of MCS are the necessary aspect in treating gastric ulcer disease.

Antioxidants have a positive effect on the metabolism and regenerative processes. They neutralize the activation of lipid peroxidation processes and restore the structural composition of membranes [2]. Phenolic compounds, being natural synergists of ascorbic acid, occupy a significant place among of numerous antioxidants and are widely represented in the plant world [3].

In official medicine, the register of anti-ulcer drugs from plants, which effectiveness has been confirmed by the experimental and clinical studies, is quite limited. The data of folk medicine concerning the gastroprotective properties of plant sources gives the wide opportunities for researchers to create new drugs that have not found application in practice of treating patients with peptic and duodenal ulcers yet.

The Brassica oleracea extract was obtained at the Department of Chemistry of Natural Compounds of the National University of Pharmacy. This extract contains vitamins: C, P, B1, B2, B6, K, D, carotene, retinol, thiamine, phenols, bioflavonoids, enzymes, mineral salts, microelements, lysozyme, glucobrassicin, neoglucobrassicin, amino acids, hormonal substances, phytoncides, and others.

The aim of our work was to study the effect of the Brassica oleracea extract on the total content of proteins and lipids of mucous cells of the stomach in the experimental ulcer.

\section{Materials and methods}

Experiments were conducted on 30 nonlinear male rats weighing $200 \pm 10 \mathrm{~g}$. Animals was kept under vivarium conditions at constant temperature and humidity. The rats were divided into 3 groups. Group 1 was intact animals. The gastric ulcer was modeled in rats of group 2 (control), it was reproduced by the combined introduction of prednisolone and ethyl alcohol [4]. Animals were kept on a starvation diet with free access to water for 24 hours. After the specified time rats were injected prednisolone in the dose $20 \mathrm{mg} / \mathrm{kg}$ and $80 \%$ ethyl alcohol in the dose of $0.6 \mathrm{ml} / 100 \mathrm{~g}$ of the animal's body weight. Prednisolone was pre-dissolved in alcohol. Starting from the second day after the ulcer modeling the animals of group 3 were introduced the Brassica oleracea extract in the dose of $50 \mathrm{mg} / \mathrm{kg}$. Euthanasia was performed by overdosing etheric anesthesia in all series of the experiment on day 16 after the beginning of the experiment.

To study the phospholipid content of membranes the lipid fraction was separated by Folch method. [5]. The principle of the method is in that phospholipids are more polar compounds than neutral lipids. They are poorly soluble in weakly polar solvents such as ether, hexane, chloroform, and separated from neutral lipids when dissolving in the mixture of chloroform and methanol $(2: 1)$. The following reagents were used: activated silicic acid; the chloroform-hexane-diethyl ether mixture of solvents $(2: 1: 1)$; the mixture of chloroform-methanol $(2: 1)$; the 1-st solvent system: diethyl ether-benzene-ethanolacetic acid (40:50:20:0.2); the 2-nd solvent system: diethyl ether-hexane (6:94). Silicic acid was used to separate phospholipids from neutral lipids.

The following procedure was used. To the centrifuge tube add $1 \mathrm{~g}$ of activated silicic acid and $50 \mathrm{mg}$ of lipids dissolved in $4 \mathrm{ml}$ of the mixture of chloroformhexane-diethyl ether $(2: 1: 1)$, stir for $15 \mathrm{~min}$ and centrifuge for $10 \mathrm{~min}$ at $3000 \mathrm{rpm}$. Then wash the layer containing silicic acid with $5 \mathrm{ml}$ of the chloroform-hexaneether mixture $(2: 1: 1)$, while the neutral lipids are washed with the solvent. Remove phospholipids adsorbed in silicic acid by 3 -time rinsing with $20 \mathrm{ml}$ of chloroform-methanol mixture $(2: 1)$.

Separation of phospholipids into separate fractions was carried out by thin layer chromatography on silica gel using the solvent system of chloroform-methanolacetic acid-water $(60: 50: 1: 4)$.

The concentration of cholesterol was determined by the enzymatic method [6] on a chemical analyzer. The colorimetric determination of free fatty acids is in obtaining the corresponding copper salts and their subsequent reaction with diethyl dithiocarbamate.

The protein spectrum of the stroma was studied by gel chromatography $[7,8]$. Separation of proteins from the stroma was performed using Sephadex G-200. The chromatographic column with the size of $2.5 \times 50 \mathrm{~cm}$ was filled with sephadex swollen in $1 \%$ solution of sodium dodecyl sulfate (DDC-Na). The empty volume of the column determined by blue dextran was $57.6 \mathrm{ml}$. The cellular stroma dissolved in the presence of DDC-Na (the sample volume of $4.5 \mathrm{ml}$, the protein concentration of $25 \mathrm{mg} / \mathrm{ml}$ ) was applied on the column, the elution rate was set to $20 \mathrm{ml} / \mathrm{g}$ (the eluent - $1 \%$ DDC-Na solution), and fractions of $2.5 \mathrm{ml}$ were collected by special micropipettes. The molecular mass of proteins in the column eluent was calculated according to the formula of G. Determan:

$$
\operatorname{Ig} \mathrm{M}=6.698-0.987 \text { (Ve/Vo), }
$$

where: $\mathrm{M}$ - is the molecular mass; $\mathrm{Ve}$ - is the volume of the yeild; Vo - is the blank volume [8].

The fractions were removed from the detergent by dialysis with $50 \%$ ethanol and distilled water, then they were concentrated with dry sephadex. The data obtained were processed using Student t-test. 
Table 1

The content of neutral lipids ( $\mathrm{Mkg} / \mathrm{mg}$ of protein) in MCS of rats in gastric ulcer on day 16 of the experiment $\left(\mathrm{X} \pm \mathrm{S}_{\mathrm{X}}, \mathrm{n}=10\right)$

\begin{tabular}{|l|c|c|c|}
\hline \multicolumn{1}{|c|}{ Experimental conditions } & Cholesterol & Triacylglycerol & Fatty acids \\
\hline Intact rats & $13.8 \pm 0.7$ & $461.3 \pm 5.1$ & $162.0 \pm 2.3$ \\
\hline Control group (ulcer without treatment) & $8.5 \pm 0.4^{*}$ & $160.2 \pm 3.4^{*}$ & $626.7 \pm 4.8^{*}$ \\
\hline Ulcer + the Brassica oleracea extract & $14.5 \pm 0.8^{* *}$ & $396.0 \pm 3.9^{* / * *}$ & $274.0 \pm 3.4^{* / * *}$ \\
\hline
\end{tabular}

Notes: ${ }^{*}-p<0.05$ compared to the intact animals; ${ }^{* *}-p<0.05$ compared to the control group.

Table 2

The content of phospholipids ( $\mathrm{Mkg} / \mathrm{mg}$ ) in MCS of rats in gastric ulcer on day 16 of the experiment $\left(\mathrm{X} \pm \mathrm{S}_{\mathrm{X}}, \mathrm{n}=10\right)$

\begin{tabular}{|l|c|c|c|}
\hline \multicolumn{1}{|c|}{ Experimental conditions } & LPH & PI & PEA \\
\hline Intact rats & $20.1 \pm 0.5$ & $45.8 \pm 1.2$ & $67.9 \pm 1.8$ \\
\hline Control group (ulcer without treatment) & $37.8 \pm 0.9^{*}$ & $18.1 \pm 0.5^{*}$ & $25.8 \pm 1.2^{*}$ \\
\hline Ulcer + the Brassica oleracea extract & $21.3 \pm 0.7^{* *}$ & $31.2 \pm 0.6^{*} / /^{* *}$ & $50.1 \pm 0.8^{*} /^{* *}$ \\
\hline
\end{tabular}

Notes: ${ }^{*}-p<0.05$ compared to the intact animals; ${ }^{* *}-p<0.05$ compared to the control group.

\section{Results and discussion}

When studying the protein content of MCS in animals with gastric ulcer it was found that the total protein content varied compared to intact rats. Thus, there was disappearance of protein fractions with the molecular mass of 72, 89, 95 and $99 \mathrm{kDa}$.

The results obtained indicated degradation of high molecular weight proteins in MCS in ulcer; it led to disorders of the regenerative capacity of the mucous membrane. After introduction of the Brassica oleracea extract a statistically significant recovery of proteins with the molecular mass of 89,95 and $99 \mathrm{kDa}$ in the total MCS fraction was determined. In this case, the protein with the molecular mass of $72 \mathrm{kDa}$ was not restored. In contrast, in the experimental model of ulcer molecular proteins with the mass of $19 \mathrm{kDa}$ disappeared when introducing the Brassica oleracea extract, along with this a new group of proteins with the molecular mass of $36 \mathrm{kDa}$ appeared. In our opinion, formation of a new fraction of proteins when introducing the Brassica oleracea extract is due to inclusion of auxiliary mechanisms that accelerate the reparative regeneration of MCS. Probably, the drug contributes to emergence of regulatory stimuli that cause the discovery of certain genes and, therefore, the synthesis of new proteins.

Cholesterol and phospholipids are the main structural components of cellular biomembranes. Cholesterol controls packaging and mobility of fatty acid chains in phospholipids, and it determines selective permeability of membranes. The complex study of the lipid content of MCS: the content of fractions of neutral lipids and phospholipids in the experimental gastric ulcer was conducted. Our studies have shown that in ulcer there are multidirectional changes in the lipid content, and it confirms participation of the lipid metabolism in development of metabolic disorders in this pathology. Thus, there was a decrease in the content of cholesterol by 1.6 times and triacylglycerol by 2.9 times (Tab. 1). The introduction of the Brassica oleracea extract to the rats resulted in normalization of the content of cholesterol to the level of intact animals and increased the content of triacylglycerol by 2.5 times compared to control.

The study of the phospholipid content of MCS in rats on day 16 of the experiment showed a decrease of the main fractions of phospholipids - phosphatidyl inositol (PI) and phosphatidyl ethanolamine (PEA) by 2.5 and 2.6 times, respectively (Tab. 2), at the same time, the content of fatty acids increased in MCS by 3.9 times (Tab. 1). In the control group it was also determined that there was the increased content of lysophosphatidylcholine (LPH) in MCS by 1.9 times due to activation of the processes of lipid peroxidation.

The introduction of the Brassica oleracea extract resulted in decreasing of the content of fatty acids by $2.3 \mathrm{ti}$ mes, LPH by 1.8 times, and increasing the content of PI and PEA by 1.7 and 1.9 times, respectively, compared to the control rats.

Thus, the results obtained indicate that the mechanism of the reparative action of the Brassica oleracea extract in the experimental gastric ulcer consisted in formation of a new fraction of proteins with the molecular mass of $36 \mathrm{kDa}$ and restoration of the lipid content of MCS. It was accompanied with normalization of the structural and functional state of the mucosa by the restitution type with complete restoration of the mucous membrane.

\section{CONCLUSIONS}

The Brassica oleracea extract in ulcerative damage of the stomach promotes the processes of regeneration of proteins and lipids on mucous cells of the stomach leading to reparation; it leads to restoration of the structural and functional state of the mucous membrane.

Conflict of Interests: authors have no conflict of interests to declare. 


\section{REFERENCES}

1. Мартинович, Г. Г. Окислительно-восстановительные процессы в клетках / Г. Г. Мартинович, С. Н. Черенкевич. - Мн : БГУ, 2006. $-154 \mathrm{c}$.

2. Окислительный стресс : патологические состояния и заболевания / Е. Б. Меньщикова, Н. К. Зенков, В. З. Ланкин и др. - Новосибирск : АРТА, 2008. - 284 с.

3. Зенков, Н. К. Антиоксидантные и противовоспалительные свойства новых водорастворимых серосодержащих фенольных соединений / Н. К. Зенков, Е. Б. Меньщикова, Н. В. Кандалинцева // Биохимия. - 2007. - Т. 72, вып. 6. - С. $790-798$.

4. Яковлєва, Л. В. Експериментальне вивчення нових противиразкових препаратів / Л. В. Яковлєва, Г. В. Оболенцева, Л. П. Брюзгінова // Доклінічні дослідження лікарських засобів : метод. рек.; за ред. чл.-кор. АМН України О. В. Стефанова. - К. : Авіценна, 2001. - С. 321-333.

5. Folch, J. A simple method for the isolation and purification of total lipids from animal tissues / J. Folch, V. Less, G. H. Slean Stanley // J. Biol. Chem. - 1957. - Vol. 226, Issue 2. - P. 494-509.

6. Безрукова, Г. А. Исследование ферментов в цитратной плазме крови / Г. А. Безрукова, В. И. Рубин, О. М. Анисимова // Лабораторное дело. - 1991. - № 3. - С. 29-31.

7. Laemmli, U. K. Cleavage of structural proteins during the assembly of the head of bacteriophage T 4 / U. K. Laemmli // Nature. - 1970. Vol. 227, Issue 5259. - P. 680-685. doi: 10.1038/227680a0

8. Детерман, Г. Гель-хроматография / Г. Детерман. - М. : Мир, 1970. - 252 с.

\section{REFERENCES}

1. Martinovich, G. G., Cherenkevich, S. N. (2006). Okislitelno-vostanovitelnye protcesy v kletkakh. Minsk: BGU, 154.

2. Menshchikova, E. B., Zenkov, N. K., Lankin, V. Z. et al. (2008). Okislitelnyi stress: patologicheskoe sostoianie i zabolevanie. Novosibirsk: ARTA, 284.

3. Zenkov, N. K., Menshchikova, E. B., Kandalintceva, N. V. (2007). Biokhimiia, 72 (6), 790-798.

4. Yakovlieva, L. V., Obolentseva, H. B., Briuzhinova, L. P. (2001). Doklinichni doslidzhennia likarskykh zasobiv. K.: Avitsena, $321-333$.

5. Folch, J., Less, V., Slean Stanley, G. H. (1957). A simple method for the isolation and purification of total lipids from animal tissues. J.Biol. Chem., 226 (2), 494-509.

6. Bezrukova, G. A., Rubin, V. I., Anisimova, O. M. (1991). Laboratornoe delo, 3, 29-31.

7. Laemmli, U. K. (1970). Cleavage of Structural Proteins during the Assembly of the Head of Bacteriophage T4. Nature, 227 (5259), 680-685. doi: 10.1038/227680a0

8. Determan, G. (1970). Gel-khromatografiia. Moscow: Mir, 252.

Information about authors:

Kononenko N. M., Doctor of Medicine (Dr. habil.), professor, head of the Department of Pathological Physiology, National University of Pharmacy.

E-mail: kononenkonn76@gmail.com

Mirzaliev M. T., postgraduate student of the Department of Pathological Physiology, National University of Pharmacy

Ostapets M. O., Candidate of Medicine (PhD), teaching assistant of the Department of Pathological Physiology, National University of Pharmacy.

E-mail: marina.ostapets.22@gmail.com

Відомості про авторів:

Кононенко Н. М., д-р мед. наук, професор, завідувач кафедри патологічної фізіології, Національний фармацевтичний університет.

E-mail: kononenkonn76@gmail.com

Мірзалієв М. Т., аспірант кафедри патологічної фізіології, Національний фармацевтичний університет

Остапець М. О., канд. мед. наук, асистент кафедри патологічної фізіології, Національний фармацевтичний університет.

E-mail: marina.ostapets.22@gmail.com

Сведения об авторах:

Кононенко Н. Н., д-р мед. наук, профессор, заведующая кафедрой патологической физиологии, Национальный фармацевтический университет.

E-mail: kononenkonn76@gmail.com

Мирзалиев М. Т., аспирант кафедры патологической физиологии, Национальный фармацевтический университет

Остапец М. А., канд. мед. наук, ассистент кафедры патологической физиологии, Национальный фармацевтический университет.

E-mail: marina.ostapets.22@gmail.com 